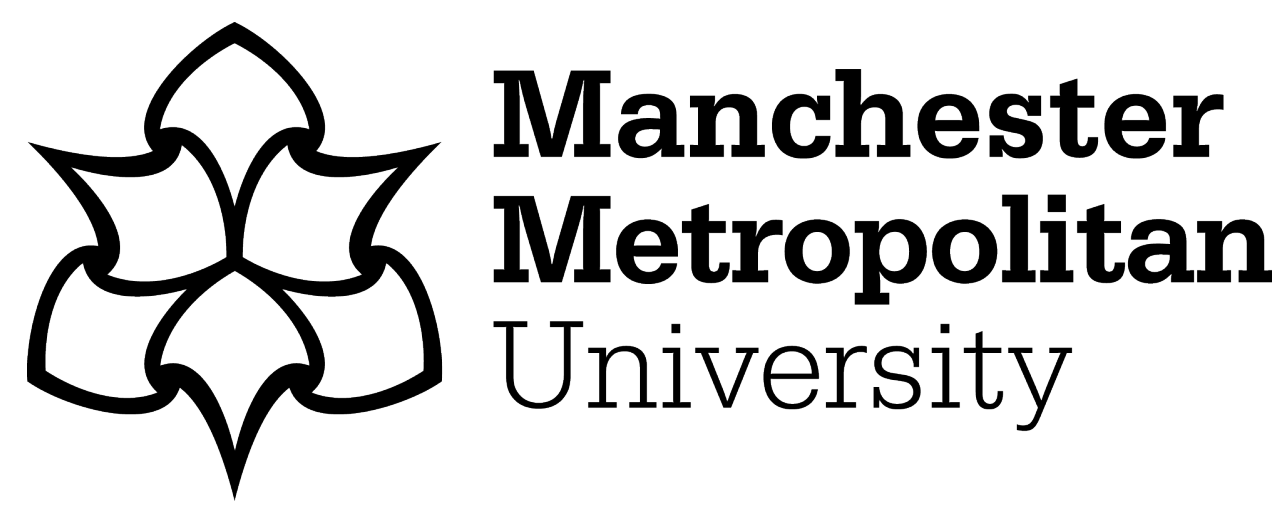

Renold, EJ and Ivinson, G ORCID logoORCID: https://orcid.org/0000-00025552-9601 (2022) Posthuman co-production: becoming response-able with what matters. Qualitative Research Journal, 22 (1). pp. 108-128. ISSN 1443-9883

Downloaded from: https://e-space.mmu.ac.uk/629043/

Version: Accepted Version

Publisher: Emerald

DOI: https://doi.org/10.1108/QRJ-01-2021-0005

Usage rights: Creative Commons: Attribution-Noncommercial 4.0

Please cite the published version 


\section{Posthuman co-production: becoming response-able with what matters}

\author{
EJ Renold \\ School of Social Sciences, College of Arts Humanities and Social Sciences, \\ Cardiff University, Cardiff, UK, and \\ Gabrielle Ivinson \\ Manchester Metropolitan University, Manchester, UK
}

Posthuman co-production

\begin{abstract}
Purpose - This paper introduces the concept of posthuman co-production. It explores how processual and relational onto-epistemologies inform an artful, response-able (Barad 2007) feminist new materialist praxis that decentres the human and re-centres matter.

Design/methodology/approach - Posthuman co-production gives prominence to crafting "dartaphacts" (Renold, 2018); creative research artefacts, carrying "what matters" and enacting change that can be mapped across time and multiple "problem spaces" (Lury, 2020), as an expansive, post-qualitative praxis of slow, co-production.

Findings - The paper stories this praxis across three "fugal figurations" providing glimpses into the postqualitative journeys of assembled dartaphacts in the policy and practice field of relationships and sexuality education (RSE) in Wales. Each fugue hints at the polytical, resourceful and living potential of dartaphacts in the making and their mattering over a period of six years. Collectively, they chart a rhizomatic journey that reconfigures co-production as a response-able, becoming-with what matters.

Originality/value - As more-than-human forces for change, dartaphacts continue to surface "the cries of what matters" (Stengers 2019) for children and young people well beyond the periods of funded research and engagement, giving new meaning to the sustainability and material legacies of research impact.
\end{abstract}

Keywords Gender, Feminist, Activism, Research impact, Sexuality, Children and young people, Post-qualitative, Posthumanism, Barad, New materialism, Participatory research, Arts-based research

Paper type Research paper

\section{Introduction: storying a "problem space"}

In this paper, we introduce posthuman co-production as a post-qualitative research praxis that decentres the human and re-centres matter. It is a praxis informed and inspired by new materialist posthuman feminisms in education or phEmaterialism [1] for short (see Strom et al., 2019). In our version of post-qualitative inquiry (St. Pierre, 2017; Murris, 2020), a research "problem" is a kind of posthuman co-production that comes from a becoming-with others (e.g. people, place and objects). As the papers in this special issue illustrate, interdisciplinary co-productive methodologies have long offered researchers multiple ways in which participatory processes complicate how a problem becomes a problem - that is, how a problem is noticed, shared and acted upon (Banks et al., 2019). Problems do not arise in advance of a project, and methodologies are not only developed to respond to a problem. Rather, methodologies are deeply implicated in creating problems, and in conducive contexts, they carry the potential to transform a problem and the world. Lury and Wakeford (2012) have, for example, demonstrated how becoming inventive with methodologies can create what Lury (2020) theorises as a "problem space" - a space that composes the problem, again

Funding: This study received funding from ESRC (Award No. ES/K002716/1), ESRC Impact Accelerator Account 2015-2016, ESRC Impact accelerator Account 2019-2020 and ESRC Impact Prize Money 2018.
Received 11 January 2021 Revised 5 July 2021 2 August 2021

Accepted 2 August 2021 
and again, itself forever changing, and with each return or revolution, something new might unfold. It is in the capacity to both create and attune to the yield of a "problem space" that gives co-productive methodologies their constitutive force and capacity to "contribute to the generative circulation of a problem" (Lury, 2020, p. 203). How problems form and transform, and how we draw upon the arts to cultivate a living ethics for becoming "response-able" (Barad, 2007) with what unfolds lies at the heart of our praxis.

A co-produced posthuman praxis of problem surfacing is indebted to and in dialogue with "indigenous scholars who have been engaging in knowledge production practices emphasising more-than-human relational ontologies for millennia" (Stengers (2019, p. 5 - see for example Todd, 2016; King et al., 2020; Truman, 2019). It is a praxis that moves research into a more direct and ethical engagement with the multiple worldings that we become entangled in. We use the term "move" here to emphasise that a phEmaterialist post-qualitative praxis is always affective and dynamic (Dernikos et al., 2020). For scholars new to the ethico-political ontologies of doing entangled research, it is a praxis that challenges what counts as research, how it unfolds and how it matters (Taylor et al., 2020). The explicit attention to the ethical, political, affective and entangled nature of "research" means that research "data" are simultaneously personal, performative and full of transformative potential. A posthuman co-production of being, becoming and making-with others, as Isabelle (Stengers, 2019, p. 19) writes, is not a process in which "academics" critique from a "safe distance", it is an "ontological engagement all the way down", a situated entanglement of being there in the thick of things.

The research praxis we share in this paper has been developed through a deep emersion in place. Our site of engagement is Wales/Cymru. We map moments in a process of attuning to the potential of a lively relationships and sexuality education (RSE) policy and practice terrain, where EJ (Author 1) is deeply embedded and becoming more and more implicated with what unfolds. It is beyond the scope of this paper to chart what Tess Lea (Lea, 2020, p. 12) might describe as the "wild" forces of Wales' RSE policy ecology, with its "natural incoherence" made up of complex interactions of multiple human and nonhuman actors. EJ has written elsewhere of the unruly, dispersed and fitful stutters and meanderings of how a wild RSE policy assemblage is taking shape in Wales (Renold, 2018, 2019; Renold et al., 2021). Our praxis dialogues with a growing scholarship of phEmaterialist (Ringrose et al., 2020a) gender and sexuality education policy and practice in schools (see Allen, 2018; Allen, 2020; Allen and Rasmussen, 2017; Alldred and Fox, 2019; Renold and Ringrose, 2017; Ferfolja and Ullman, 2017; Quinlivan, 2018; Osgood and Robinson, 2019; Robinson Garland-Levett, 2020; Ringrose et al., 2020b; Pasley, 2020; Marston, 2020; Wolfe, 2021; Timperley, 2021; Zarabadi, 2021; Mohandas, 2021). It is a shared praxis which we, EJ and Gabrielle (Author 2), share and theorise regularly.

The next three sections of the paper open up the processual ontology informing our praxis and our core concepts of "queer response-ability" (Barad, 2007) and "dartaphact" (Renold, 2018). What then follows are three "fugal figurations" each crafted to provide glimpses into post-qualitative journeys of collaborative phEmaterialist praxis. Each fugal figuration hints of slow co-production with dartaphacts as key players transforming what matters in unexpected ways across micro- and macro-political force fields of RSE to come. The ethicalpolitical praxis of slow posthuman co-production is further expanded in the final Coda.

\section{Co-producing what matters with queer response-ability}

Barad's (2007) queering of Haraway's (1991, Haraway, 2016) portmanteau response-ability has the potential to reconfigure co-productive methodologies. We unpack this generative concept by exploring the ethical onto-epistemological implications for our phEmaterialist praxis. Barad's concept of "queer response-ability" has three major strands. First is the recognition that the researcher is always already part of the phenomena being investigated. A posthuman co-productive praxis thus requires a processual ontology that dissolves the Cartesian boundaries between human and non-human matter, subject and object and researcher and 
researched and puts matter into dynamic motion. Accordingly, epistemology is entangled with ontology as "onto-epistem-ology - the study of practices of knowing in being" (Barad, 2007, p. 185). Second, what "matters" is an ongoing and dynamic process of differentiation in which agency is not restricted to humans. In this posthumanising of agency, what happens or what comes to matter is not causal or sequential, but involves researchers making an "agential cut", which has implications for what becomes visible or knowable as "data". This leads to the third component. Barad's onto-epistemology is an ethical-onto-epistemology. Matter comes to attention through an agential cut that will always involve issues of in/justice and in/equity where "matters of concern and matters of care are shot through with one another" (Barad, cited in Kleinman, 2012, p. 69).

Barad conceptualises ethico-onto-epistemology as a "queering" of response-ability. Response-ability, is "not about the right response, but rather a matter of inviting, welcoming, and enabling the response of the Other" (Barad, cited in Kleinman, 2012, p. 81). Queer response-ability, she argues, involves paying attention to the ways in which phenomena are always becoming Otherwise, what she terms the "queer-ness of phenomena" (Kleinman, 2012). The queerness of enabling and welcoming Other ways of being-knowing-responding in the field of RSE has multiple implications for us. The response-ability of becoming Otherwise in this context involves cultivating the "ability" to make space and time for conducting researchengagement-activist projects designed to attune and communicate the experiences of children and young people in ever changing micro- and macro-political contexts (see also Bozalek and Zembylas, 2017). As we go on to illustrate below, this involves entangling with the often complex, volatile and ever-differentiating world of how gender and sexuality education is mattering for diverse publics (Talburt, 2018; Blaikie, 2021; Martino et al., 2021; Mamo et al., 2021). Implicit in our research praxis is an ethical and political responsibility to call out practices which subjugate, silence, sensationalise and simplify children and young people's experiences (see Gilbert, 2021) and "stay with the trouble" that comes to matter (Haraway, 2016) as events unfold (Renold and Ringrose, 2019; Renold and Ivinson, 2019).

\section{Dartaphacts: making way for what might come to matter}

We have many years of experimenting with different art materials and artists on methodologically funded projects designed specifically to problematise participatory (Renold et al., 2008) and co-productive methodologies (Ivinson and Renold, 2013, 2016; Renold et al., 2020a, b). Over time, we have noticed how events can sometimes unfold in generative ways with and for young people. We have learned to become more inventive in crafting ethicopolitical spaces, techniques and materials that enable a form of co-productive participation where the proto possibilities of feelings and ideas flow and are transformed though words, artefacts and new events.

Erin Manning (2016) refers to the medieval notion of art as "the way". Manning argues that to conceive of art as the manner of how we engage helps us glimpse "a feeling forth of new potential" (Manning, 2016, p. 47). In doing so, it subverts and scaffolds accountability on the journey of coming to know differently through creativity as a way to notice the always already queerness of the world and imagine otherwise. This is not about utilising arts-based methods for "data" that are waiting to be collected. Like many post-qualitative arts-based youth research/ers (see for example Coleman et al., 2019; Hickey-Moody et al., 2021; Huuki et al., 2021), the art in our praxis is a processual, relational and transformational notion of art-as-way (Manning, 2020, p. 22) - a process of creating ethical-political spaces for surfacing what matters. Barad's call to become response-able has enabled us to recognise how our research praxis matters and to work with the affective politics of what comes to matter (see Meissner, 2014; Massumi, 2015). Our concept of the "dartaphact" has accompanied us on this journey.

Massumi argues that "art is about constructing artefacts - crafted facts of experience so that experiential potentials are brought to evolutionary expression" (2013, p. 57). The concept 
"dartaphact" mixes data, art and act/ivism in processes that make the mattering "facts of experience" visible to wider publics. The concept is deliberately ambivalent about being an object (artefact) and a verb: the artful making of experiential facts. The first half of the concept - darta - (hybrid of data and art) is an explicit intervention to trouble what counts as social science data which emphasises and values the speculative process of what comes to matter through arts-based research. As mentioned above, the second half of the concept phact - signals the explicit posthuman ethico-political activist potential of what matter can do. The "ph" at the heart of the concept replaces " $\mathrm{f}$ " in dartaphact to register the posthuman forces of artful objects as potential political enunciators and to encourage a move away from the illusion of objective, fixed, knowable and measurable social science facts. In making this paper, we have extended our previous use and understanding of dartaphact to include any matter (human and more-than-human, from visual arts objects to research reports and websites), which operate in this way and carry transformative potential to agitate and enact change. Indeed, darta and dartaphact have become useful post-qualitative concepts for praxis both within and beyond the academy as they re-animate what research can do when ethicopolitical creativity is folded into the mix (see Renold et al., 2021, pp. 21-22).

\section{Posthuman co-production with RSE agendas in Wales: three fugal figurations}

Becoming able to respond to "what matters" is an embodied and embedded ethical practice that will always take place within "specific histories of particular practices of engagement" (Barad, in Kleinman, 2012, p. 81). The journey we chart in this paper also pays attention to how the politics of place matters (Tuck and McKenzie, 2014), including the politics of devolution in Wales/Cymru since 1999 [2]; the lively history of third sector feminist and LGBTQ + partnerships [3]; a national Futures and Well-being Act (Welsh Government, 2015) [4]; a national Violence Against Women, Domestic Abuse and Sexual Violence Act (Welsh Government, 2019) [5]; a progressive political legacy that legislates for children's rights, equity and social justice [6]; a children's rights-based approach to sex and relationships education (Welsh Government, 2010) and a radical overhaul of a national curriculum, which involves teachers, pupils, stake-holders and academics (Donaldson, 2015). Over time and in different ways these terrains entangle to open up and close down the fields of potential for dartaphacts to form and inform the field of RSE in Wales. They have operated as vital forces that at times we, as researchers, could align with and at other times were propelled from. Together they mark out a dynamic "problem space" that circumscribed our praxis.

We share the unfolding of a creative praxis over six years as an emergent artful theory doing as situations developed and became available. It is a praxis that opens up research to its more-than, rupturing individualistic, linear and neo-liberal research impact agendas (Bell and Pahl, 2018; Facer and Pahl, 2017; Taylor et al., 2020). We trace the journey of how dartaphacts in the three fugal figurations below have become and continue to become micro-political enunciators, carrying what matters and enabling and enacting change. Drawing on EJ's musical background, we take inspiration from the Renaissance fugue, as a contrapuntal composition of multiple voices built upon a subject which, unfolds and recurs in improvised form. In our story, the subject of the fugue is the emergent field of RSE in Wales, and the multiple voices are the dartaphacts that attune to and traverse the terrains of the problem space. Haraway captures the process of doing co-productive research as "figuring" that is "practice and process: a becoming-with each other in surprising relay" (Haraway, 2016, p. 3). Lury (2020, p. 40) drawing on Haraway writes,

"methodologically speaking figuring involves the activation of methodological potential in a process that is neither teleological nor mechanistic" and where a problem does not proceed "from givens to goals, but instead is a becoming-with". 
Each fugal figuration provides a glimpse into the polytical, resourceful and living potential of dartaphacts in the making and their mattering. We have written the fugal figurations to describe the affordances of human and more-than-human becomings that coalesce into dartaphacts. We include images and references to publications (e.g. academic papers, research reports, films and resources) to enable readers to connect with the many players, terrains and discourses circumscribing this research-activist praxis. These citations can also be drawn upon by readers unfamiliar with the field of RSE and point to the various research and engagement projects that yielded the dartaphacts in the figurations that follow.

\section{Polytical dartaphacts}

Matter makes itself felt [. . . ] matter feels, converses, suffers, desires, yearns and remembers (Barad et al., 2012, p. 48)

The first fugal figuration starts in a secondary school in an ex-mining valley town in South Wales. During a project designed to explore feelings of safety growing up in a post-industrial place (Renold et al., 2020a, b), the research team [7] became aware that some young people had knowledge of sexual violence. Some of the girls were keen to participate in a more activist phase of the research to explore this theme further. EJ set up a lunchtime meeting, and a group of six girls began to work with the anonymised interview transcripts where sexual violence surfaced (Libby et al., 2018). Part of this work included a tentative aim to see how the data might inform political change and lend support to the education amendments of the new Violence Against Girls and Women, Domestic Abuse and Sexual Violence (VAWDASV) bill, which happened to be progressing through the Welsh Government at the time. The emergent praxis unfolded into what became the Relationship Matters lunchtime project (see Renold, 2018). It gives the first heART beat of what a phEmaterialist co-productive praxis feels like.

During one of the sessions some of the girls talked about how their own and others' experiences of sexual harassment and violence left them with "lumps" in their throat, a "turned stomach" or "just numb" and speech-less. They talked about wanting to keep their "feelings in" and simultaneously wanting to express them outwards. Attuning to their desire to both feel and express, EJ invites the girls to communicate not through words but through marking a pile of paper from a previous workshop - pieces of paper that had been printed with multiple images of rulers. Why rulers? Because in the earlier session, the comment, "sometimes boys lift up girls" skirts with rulers' prompted a dartaphact made up of paper rulers on which girls had written messages calling out the "cat calling" they experienced. They called this dartaphact, the "shame chain". Later they used acrylic rulers which they turned into a ruler-skirt (Renold, 2018, Figure 1).
Posthuman co-production 
The girls seemed puzzled but intrigued by the invitation to work with paper. Like the making of the ruler-skirt, what followed was a process where meaning, matter and affect entangled in ways that none of us could have predicted. They immediately began scrunching and ripping up the ruler-lined paper, talking about how "it's better to get your anger out on something" and the "sense of relief" they felt in doing this. One of the girls corrects EJ in describing how her feelings (are literally) matter - a moment of "empirical attunement" (Stewart, 2014, p. 126) that has stuck with EJ and will forever capture young people's awareness of how "matter makes itself felt" and where the "thing felt is fringed by an expanding thought-pool of potential that shades off in all directions" (Massumi, 2013, p. 50):

It's like a sense of relief for me.

\section{EJ: A sense of relief?}

Yeah [.. .] how you react like [...] your feelings [.. .] rips them up and crumples them up until there's practically nothing left and you're left in pieces. And I reckon using paper is actually a good way of expressing that.

EJ: So you're thinking about your feelings inside the paper?

\section{My feelings ARE the piece of paper.}

\section{EJ: Are the piece of paper?}

Like crumpled up, torn up into little tiny pieces.

In the space of a few minutes, a large pile of torn pieces of paper materialised: the rule(r)s were ripped to shreds. Staring at the pieces they discuss what to do with them. Some girls wanted to keep them. Others wanted to "chuck them away". The idea of binning the shredded papers alarmed the girl in the extract above who shrieked, "but that's chucking my feelings away!" EJ wonders out loud "what else might we do with the pieces", and the same girl glances at the green recycling bin. "Recycle them!". They decide to make a heart, with the following words: slag, fake, how much do you charge?, wolf whistling, rumour, grabbing your bum, stuck up, youth mother's a MILF, bitch, fatty, sket, beeping, look at her arse, ruler-like and fanning out from the heart (Figure 2).

They decorated the outside with cracked clock faces. Later they reflect on this process and drawing on an audio transcript from the session co-authored chapter with EJ writing:

Figure 2. Tagged HeART dartaphact

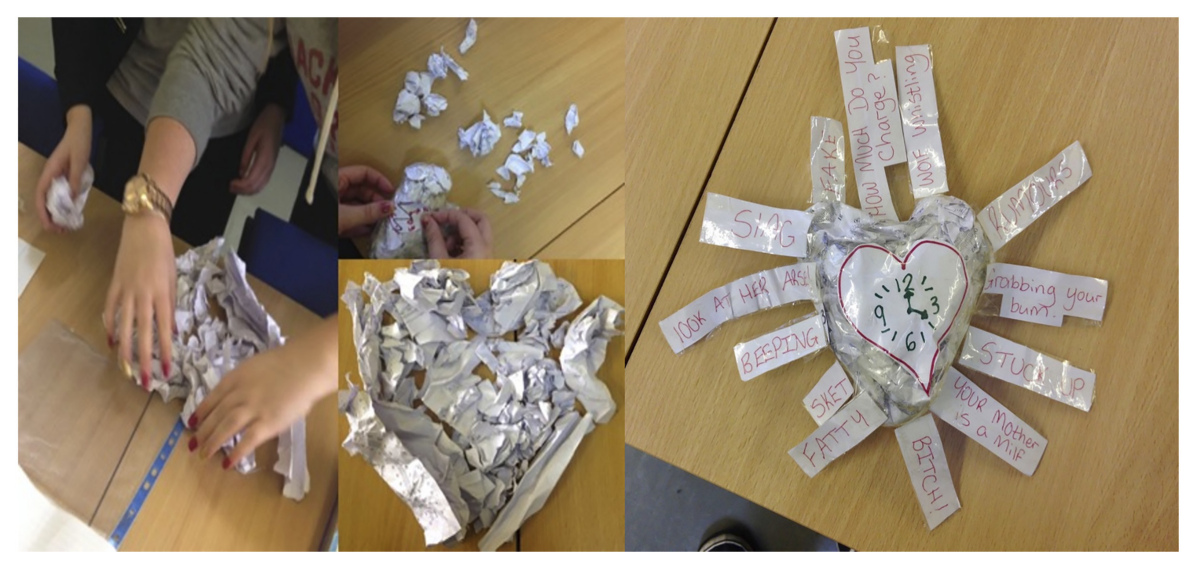


We did not want to throw our feelings away. Instead, we collected them all up and decided to make a heart. We drew clocks on the heart to show that time can heal. But the clocks also have cracks on them, to show that time can't heal everything. We put the hurtful words on the outside of the heart we did not want to hide what happens to girls any longer (Libby et al., 2018).

The Tagged HeART joined the other dartaphacts, including the ruler-skirt, the shame-chain the runway of disrespect and the poem, "Speak Out". These were used in two school assemblies they delivered on the theme of "healthy relationships" in which they invited other young people to "feel what we feel". Indeed, the school assembly was a pivotal moment in which EJ, and the girls were learning together how to create what Stengers (2019) calls a "sensible event" with dartaphacts as participants. A sensible event involves "allowing oneself to be touched, and allowing what touches you the power to modify the way you relate" (Stengers, 2019, p. 16).

At the end of the two school assemblies, students were invited by the girls to take part in a piece of political activism. Each student had the opportunity to complete the sentence: "We need a healthy relationships education because [.. . ]" printed on the one side of a paper ruler and create darta to inform the draft VAWDASV bill. Keeping the heART in play, three paper rulers were glued inside a cut-out heart of a tri-folded red card (Figure 3). Every assembly member (AM) in Wales (60 in total) received a hand delivered valentine card (see Renold, 2018

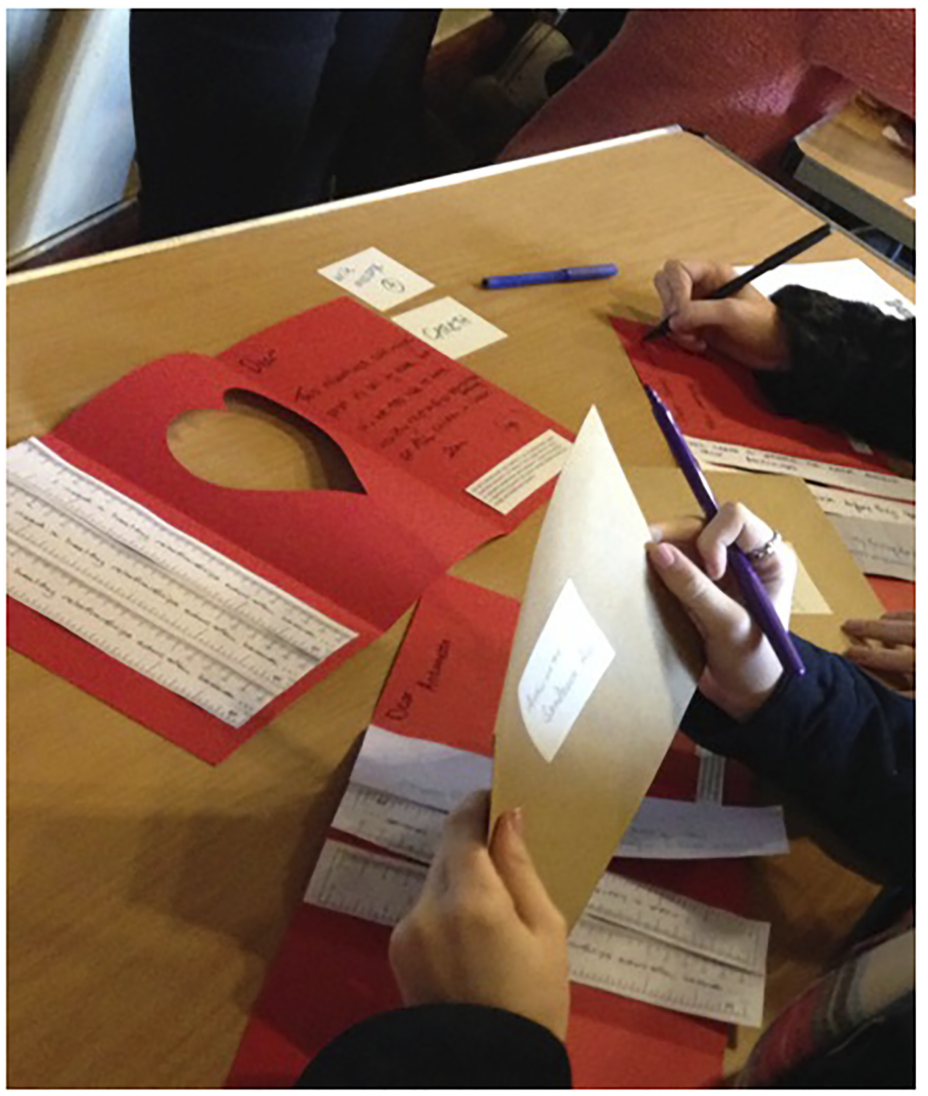

Figure 3. Valentine card HeART activism 
for further details). The minister in charge of the bill, received a specially large card with the image of the Tagged HeART on the front cover and over 20 paper rule(s) attached (Figure 4) another moment of empirical attunement which he remembered three years later when he and EJ shared a platform in a panel on research and policy impact.

EJ tweeted each AM's professional twitter account to see if they received their card. This led to a number of rewteets and responses from across the political spectrum with comments that supported the recommendations detailed in the cards. The AMs were touched by the creative delivery and although we cannot know how or why the dartaphacts moved them, a passage was created, something was indirectly evoked that put them in touch with what mattered. We can speculate that the dartaphacts opened out the usual parliamentary processes and supported AMs to take a stand on a difficult subject. A "sensible event" (Stengers, 2019) was forming and informing a policy field in the making.

On the 10th March 2015, the bill gained royal assent as the VAWDASV Act (Welsh Government, 2015a). It included many of the Relationship Matters' campaign's education amendments for mandatory teacher training on relationships education and a whole school guide for educational practitioners, which was published later that year, and included the rulerHeART story as an example of "good practice" (Welsh Government, 2015b, pp. 9-10). However, making RSE mandatory was postponed for the new curriculum (we return to how the valentine card activism has continued to matter, below). The ways in which the emergent praxis in the Relationship Matters project directly informed the making and mattering of the Valentine Card HeART activism marked another significant moment for EJ's experiential understanding of the force of dartaphacts in co-productive processes. EJ recognised the limits to academic "critique" given that a year of written and oral submissions of evidence had been futile in materialising Article 12 of the United Nations Convention on the Rights of the Child (UNCRC), which states that all children should be part of decision-making processes. The dartaphacts created passages and ruptures in the usually acceptable modalities of how academics and politicians work uncovering a new "problem space" for how to communicate what matters.

Figure 4.

Tagging the minister

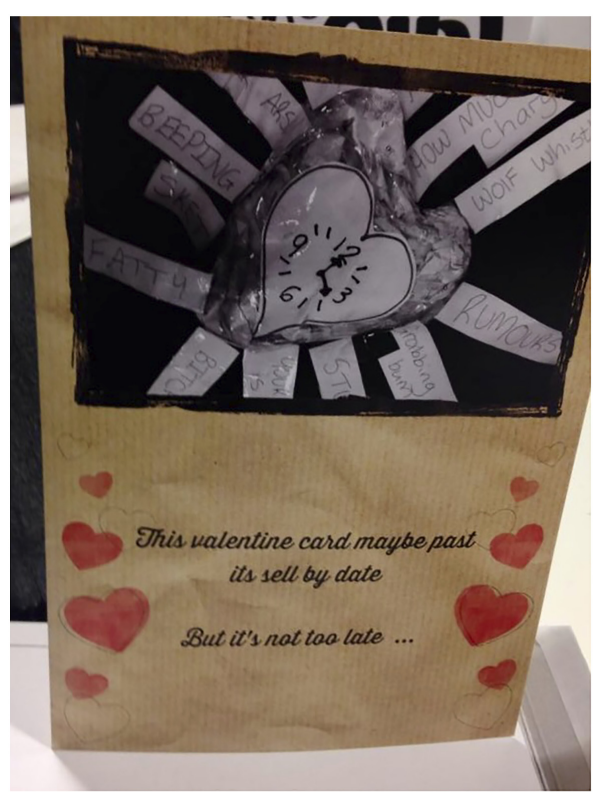


Massumi (2013, p. 173) has argued that "politicality" as distinct from conventional political platforms, programs and parties "is always on its leading edge, affective". Our re-working of poly in political (polytical) is to emphasise the fugal quality of a praxis that was "gaining a foothold in multiple political registers" (Guatarri, 1995/2006, p. 128), in a lunch group, a school assembly and community arts activism. Dartaphacts carrying what mattered were traversing micro- and macro-political contexts. The next figuration traces how injecting some ethical vertigo into the United Kingdom's (UK) research council's "impact" agenda enabled the emergent praxis to continue on its way.

\section{Resourceful dartaphacts}

The passing of the landmark VAWDASV Act was a rare a moment when micro- and macroalliances were forged with "processual reciprocity" (Masumi, 2015, p. 81). A grassroots movement was proliferating "without being confronted with major obstacles" (Masumi, 2015). An opportunity emerged as the new whole education guide for healthy relationships was celebrated on twitter by the minister in charge of the Act and who had received the Tagged HeART Valentine Card. EJ seized the moment and tweeted "how about a guide for young people?" The minister tweeted an immediate affirmative response. EJ carefully crafted a speculative proposal for co-producing a guide with young people.

A lively exchange of emails between Welsh Government and two key agencies, Welsh Women's Aid and NSPCC Cymru garnered enough support to secure funding from the Economic and Social Research Council's (ESRC) "impact" stream. Over the next nine months, EJ co-produced the Safe To Act, Right To Engage and Raise (stARTer) project. The acronym, stARTer, registered the beginning of an artful praxis with an advisory group of 12 young people from three different schools, including two of the members from the original Relationship Matters project. During the process, well over 50 young people participated in what eventually became "AGENDA": a young people's guide to making positive relationships matter (see www.agenda.wales).

AGENDA is the title of Wales' first bi-lingual (Welsh-English) national resource addressing gender-based and sexual violence co-produced with young people over a year. The process involved three days of meetings with the young people and the wider team (see www.agenda.wales, p. 73), between six and eight site visits to three core schools and over 15 site visits to other schools and youth groups. The young advisory group did not want to be "told" in an authorial voice what they needed to know, feel, do, become or act (see Coll et al., 2019). Rather, they wanted a process that allowed them to experiment and explore their own matters of concern and connect with the concerns of others. They wanted to include a diverse range of experiences, such as LGBTQ+ rights to misogynoir in the music industry (Renold, 2019).

AGENDA's explicit activist philosophy draws on the ethical-political aesthetic yield of making what matters come to matter. The Latin roots of the term agenda mean "a doing - a driving force and an impulse" (Renold, 2019, p. 21). The co-production praxis was developed in the Relationships Matters project (Figure 5) and invites participants to keep what matters lively and open to change as dartaphacts touch and connect experiences.

While many of the activities in the resource combine arts-based methods (e.g. drama, poetry, visual arts, dance, etc), it is AGENDA's approach to creativity, as the processual "making" of "matters", which functions as the beating heART of this fugal resource. Each case study opens up a range of issues to multiple variations (see Figure 6) and includes 'Do it Yourself' (DIY) activities for others to adapt and make their own.

In collaboration with multiple partners who share AGENDA's vision to "Be Creative [8]" in how to "Make Voice Matter Differently" (see www.agendaonline.co.uk/agenda-information) and tapping into various impact and engagement funding streams, AGENDA has evolved 
QRJ

Figure 5.

AGENDAs HeART activist beginnings

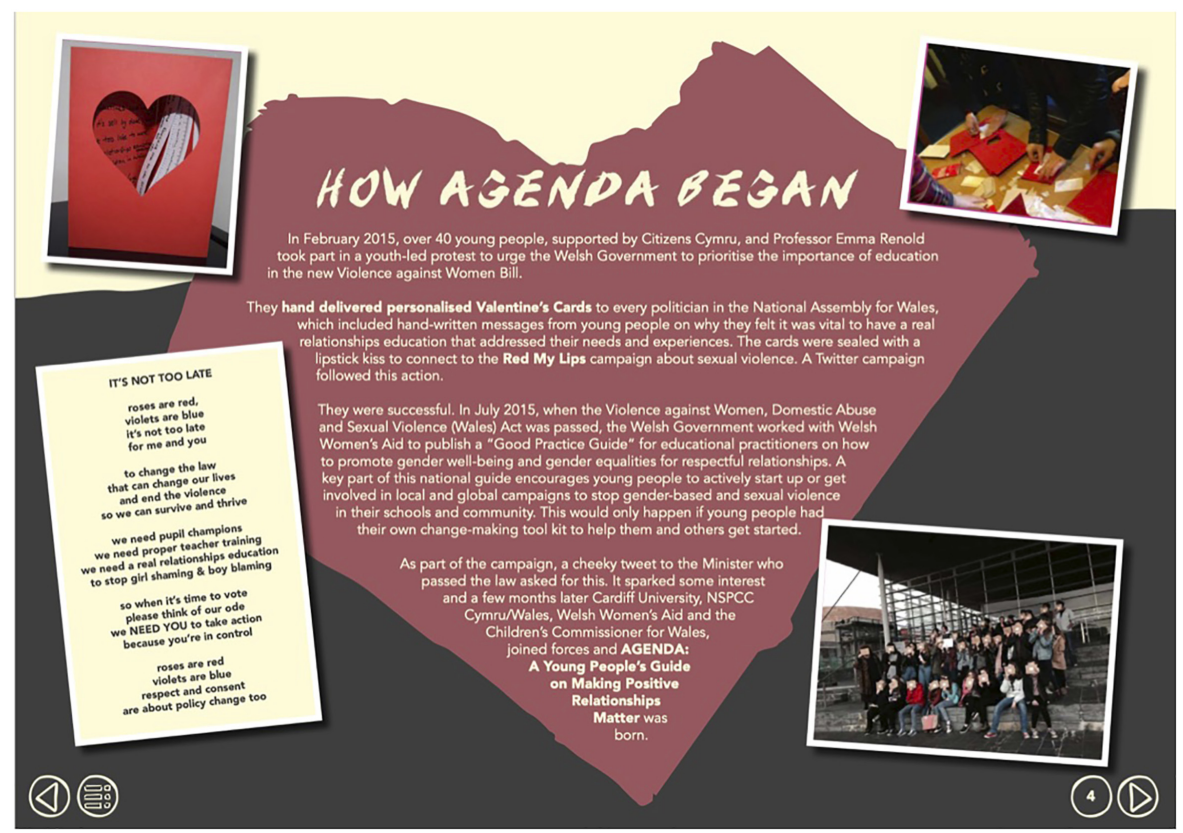

into a practitioner guide for primary and secondary schools. Over the years, the guide has become resourceful for both distilling and expanding a praxis, yet also eventful in platforming a praxis that continues to make a thousand tiny dartaphacts that carry traces of what matters to young people in relation to gender and sexualities (see www.agendaonline.co. uk). Indeed, since its launch, we have been learning how to enable dartaphacts to touch, move, inform and transform multiple local and national polytical agendas [9] through AGENDA outreach workshops, conferences (Renold et al., 2019; see Figure 7) and professional learning events (Renold et al., 2020a, b):

However, lifting the silence on what matters for children and young people with an explicit rights-based, activist, curious and creative praxis brings risks. Each year since AGENDA's launch, twitter, social and news media and public attacks have been directed at EJ, Welsh Government, key stakeholders, participating schools, youth groups and at the AGENDA resource itself. Each time, we are alerted to how surfacing what matters creates trouble. While such attacks rattle us and temporarily still or flatline a flow, the more-than-human dartaphacts generated though AGENDA's praxis remain in the world and continue to have impacts. AGENDA takes root in new sites and flourishes like a living organism, attracting attention with known and unknown effects and affects while continuing to inform policy and practice as the final fugue describes.

\section{Living dartaphacts}

Six months after the launch of the AGENDA resource in March 2017, EJ was invited by the Minister for Education to chair a panel of experts examining the current and future status of the Healthy Relationships' Education curriculum in Wales. At that time, the policy context for the then, "Sex and Relationships Education" (SRE, Welsh Government, 2010) was nonmandatory. We were learning fast from the AGENDA conferences that SRE was reaching a 
Posthuman co-production

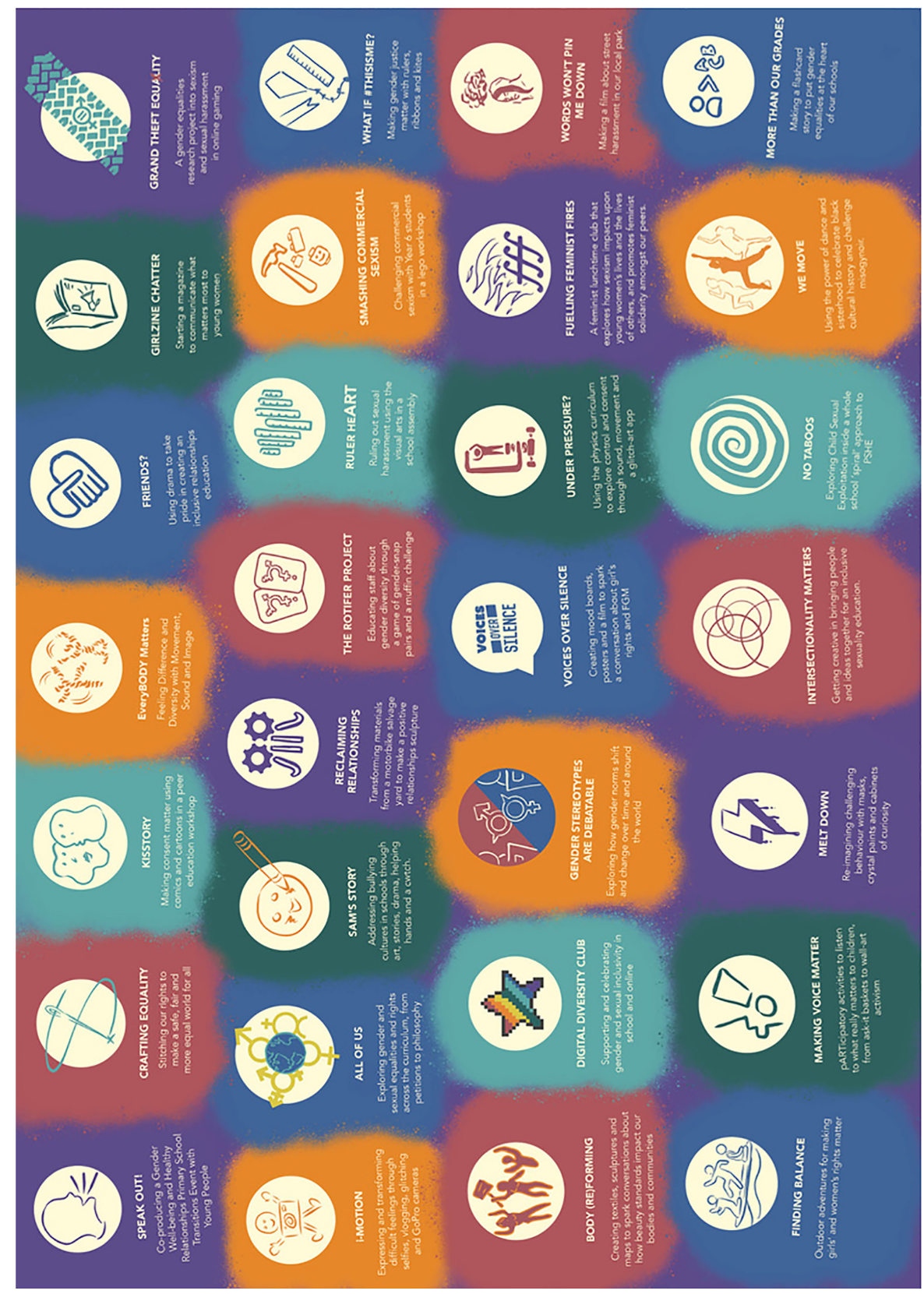

Figure 6. Dartaphacts making a difference 
tipping point. The gulf between school-based SRE provision and what young people wanted from their SRE and their lived experience was widening. Accordingly EJ requested a change in the terms of reference so that the original focus on healthy relationships education included sex education. This was agreed by the minister and the expert panel on sex and relationships education was announced (https://www.cardiff.ac.uk/news/view/592589-new-experthealthy-relationships-group-to-advise-on-curriculum).

This first meeting with the expert panel was crucial. It became clear that the Welsh Government's understanding of "expertise" and "co-production" were firmly rooted in a neoliberal notion in which "academics" in universities are plucked from their ivory towers to assemble "evidence" that informs a policy or practice (in this case both). The process of chairing an "expert panel", when the key experts on "what matters" are notably absent from the process and in a time-frame that could not meaningfully engage children, young people (or their parents, carers and communities) were deeply unsettling. EJ's status as "chair", both as a professor and as the leader of the panel, became fraught and in danger of betraying the collective and more-thanhuman, co-productive praxis through which EJ had been hailed as an "expert" in the first place. The problem space, pre-defined by the government, needed re-defining.

The panel met five times over a seven-month period. Each meeting was carefully crafted by EJ to enable the group to slowly re-imagine what else SRE could become. "Evidence" included dartaphacts created in local AGENDA workshops (e.g. objects and films), a reading list made up of traditional research reports, academic papers, books from around the world and a series of presentations [10] (see appendix 6, Renold and McGeeney, 2017a). Only a short report outlining the panel's rationale and recommendations was expected (40 pages). However, with support from Dr. Ester McGeeney (an experienced youth practitioner and sexualities researcher) an additional and much longer 160-page report was written (Renold and McGeeney, 2017b). This report expanded the 12 recommendations in the short report and provided examples of praxis and a future vision. As Massumi (2017, p. 105) argues, "what is needed in political action is not a hope, but a way".

At the end of the process, a vision for a new "living curriculum" emerged. A living curriculum, as Snaza and Mishra Tarc (2019, p. 2) argue, is the very opposite of "the dead, established and revered text, not as a set of facts, a subject area to be studied, but as ontoepistemological". The panel had a vision of a rights and equity based, creative, transformative, holistic, inclusive and co-produced RSE. The longer report included a meta-synthesis of international research as well as case studies from the AGENDA resource, replete with images of dartaphacts foregrounding young people's experience. We came to realise that reports are dartaphacts as they explicitly signal what matters. EJ purposefully selected an image of the ruler heART valentine card to adorn the recommendations page and an AGENDA dartaphact indicating what young people what to "stop and start for a better SRE” on the front page (Figure 8).

Figure 7.

The Minister of Education reaches into a rainbow pinata to read out messages from primary school children what they want from a more LGBTQ + inclusive RSE at the 2017 AGENDA conference

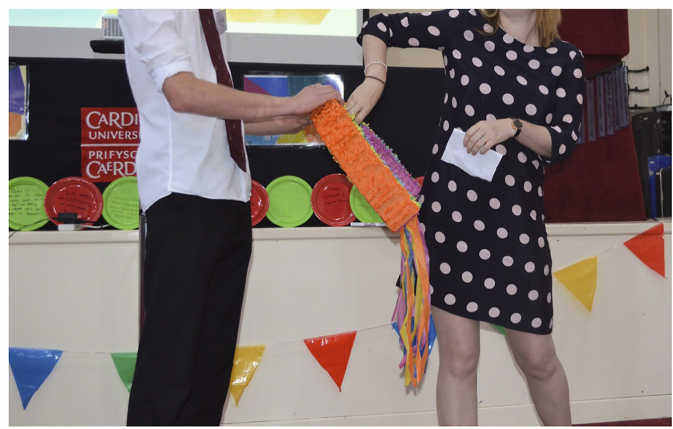


The images carry haunting legacies of "what matters" to young people. While most "chairs" of expert panels return to the ivory tower after their parliamentary work is over, EJ persists in actively creating the conditions through which dartaphacts continue to be meaningful through on-going work with teachers, young people and third sector organisations. This ongoing work propagates the panel's vision, enabling the emerging and newly named RSE curriculum to take root in schools across Wales and beyond.

It is six years since the Valentine Card activism and four years since the recommendations of the expert panel were accepted by the minister (for a summary, see Renold, 2017). EJ has since been choreographing the polytical at both the macro- and micro-level simultaneously: as official advisor to the new co-produced RSE curriculum, and developing, resourcing and platforming (https://vimeo.com/416352195) an evolving, experimental professional learning programme with an AGENDA informed praxis with Dr. McGeeney and more recently, Dr. Leanne Coll, Dr. Kate Marston and Dr. Vicky Timperley (Renold et al., 2020a, b, Renold et al., 2021 - Figure 9). This ongoing praxis enables teachers to creatively co-produce dartaphacts with their students to inform a "living curriculum" in their schools in ways that both starts and stays with "what matters" for children and young people (Ollis et al., 2022).

Slow co-production matters. As the new curriculum bill (Welsh Government, 2020) gained royal assent following the conventional political processes in Wales, the proposed new and statutory RSE (age 3-16) comes under attack. Petitions, social media and street protests marshal a rising post-truth politics. Such events tend to silence how gender and sexuality "matter" to children and young people. EJ was invited to the only evidence session scheduled for RSE and facilitated by the Children and Young People's Education Committee tasked with scrutinising the bill. When asked about the rationale for why Wales' new RSE matters, EJ held up one of the original ruler-bearing valentine-cards and opened it to open up "matters" (Figure 10).

Dartaphacts continue to carry the legacy of what children and young people want from RSE as the bill becomes an act (Welsh Government, 2021). On UK RSE Day (24 June 2021), EJ

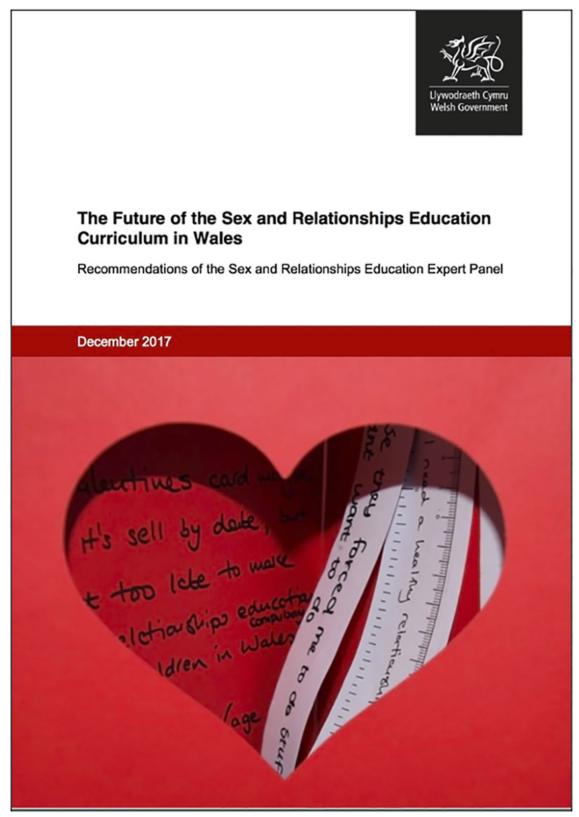

Posthuman co-production






\section{QRJ}

\section{Figure 9.}

Re-image-ining what matters
Figure 10.

Dartaphacts strike back

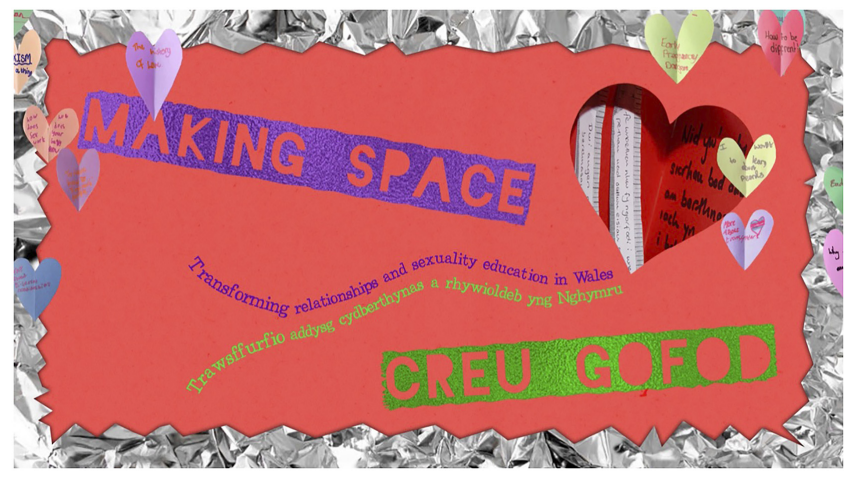

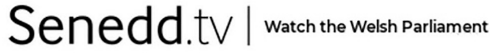
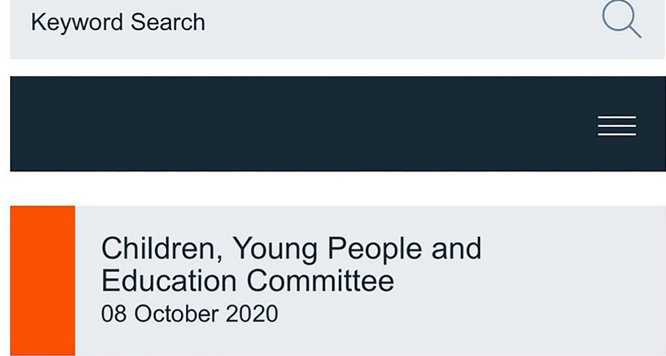

Children, Young People and Education Committee 08 October 2020

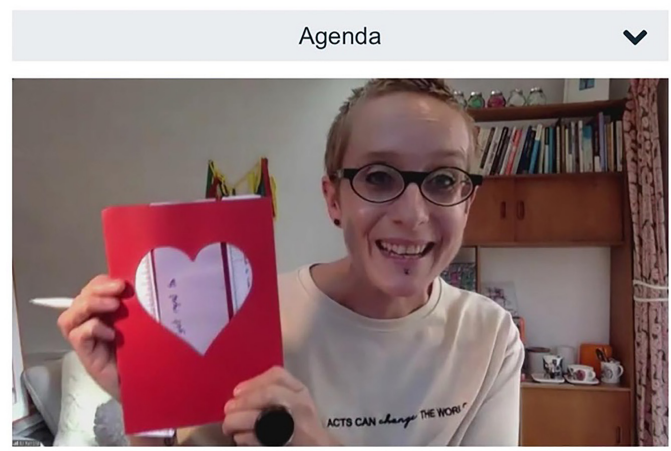

facilitated Wales' first online RSE professional learning conference for teachers [11] (www. agendaonline.co.uk/agenda_matters/). The ruler-heART returns in the illustrated programme (see Figure 11). Ensuring that the conference opens with matter, as soon as participants arrive they are greeted with a 15-minute digital gallery of RSE dartaphacts made with or by children and young people (see https:/vimeo.com/566804734) - dartaphacts created in over 20 research, engagement and teacher inquiry projects (see Figure 12).

The sustainability of dartaphacts to communicate and enact change continue to affect and impact. In this way, they are participants in a slow praxis of embodied and materially embedded, more-than-human co-production. 


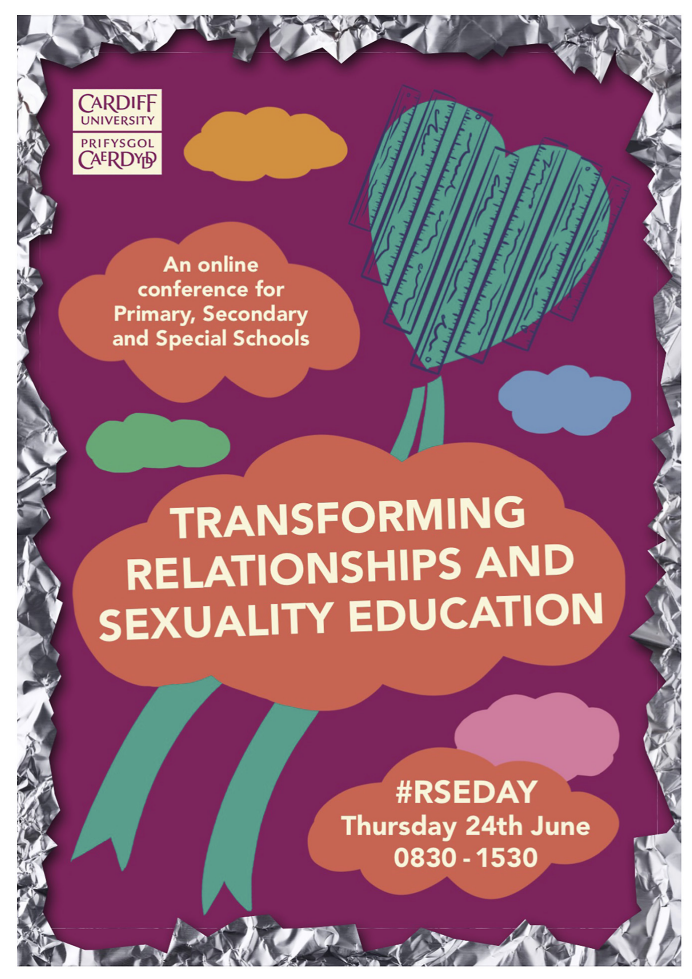

\section{Posthuman co-production}

Figure 11. Transforming RSE online conference

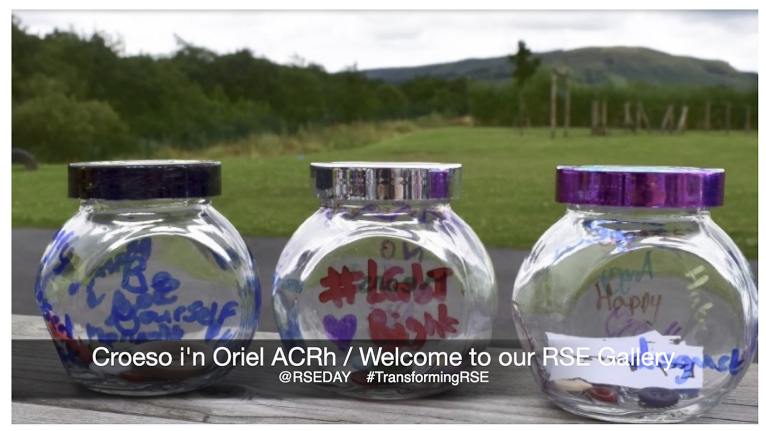

Figure 12. Digital gallery of RSE dartaphacts

\section{Coda: figuring out how posthuman co-productions come to matter}

Responding to the insistence of the cry "it matters" does not mean justifying its claim [ . . . . It means intensifying it [... . giving it the power to problematize [. . .] and make things matter (Stengers, 2019, p. 16).

In our post-qualitative, posthuman co-productive praxis of engagement, we give prominence to the role of dartaphacts to make things happen. In the three fugal figurations, we have shared the unfolding of a creative RSE praxis across six years. Each fugal figuration assembles a dartaphact as "a figure for ongoingness" (Haraway, 2016, p. 2) and together they 
chart a rhizomatic journey. We have hinted at the power of dartaphacts to create, anchor, register and carry what matters for children and young people through a range of micropolitical, resourceful, eventful and performative ways. Dartaphacts are emergent phenomena - artefacts/matters "not of reason but of pure feeling" (Manning, 2020, p. 24). The artfulness of doing and making involves a potential that runs through events, a potential that might or might not become actualised. Dartaphacts such as the tagged heART or ruler-skirt are layered composites that materialise emergent feelings and concerns with aesthetic yield (Manning, 2020, p. 22). Once launched into the world they continue to affect, move and give rise to further events. Indeed, our RSE dartaphacts have affected, moved and sometimes troubled politicians, policy-makers and teachers. As situations developed and became available dartaphacts yield further dartaphacts, such as the Valentine Cards, and the AGENDA resource and become lively in various ways: they re-animate "evidence" in parliament and governmental expert panels; create RSE practices that enable young people to express what matters to them and through artful learning conferences inspire teachers to embed a living RSE curriculum as an on-going, creative process - a living RSE pedagogy. In these processes, new problem spaces continuously surface. Collectively, the fugues illustrate slow coproduction is a becoming-with what matters.

Posthuman co-production is not a matter of adults "representing" children or young people's experiences or giving the multiplicity of their "voices" an equal chance to register (Mayes, 2019). Rather, it is about inviting, enabling and creating space and time for the multiplicity of what matters to unfold and become materially realised. For us, co-productive research is art-as-way (Manning, 2020, p. 22), an artful praxis that enables what concerns young people to move into expression. It opens research to the more-than of life in its contingency, rupturing individualistic, linear and neo-liberal research and engagement impact agendas (Bell and Pahl, 2018; Facer and Pahl, 2017; Pahl, 2019; Taylor et al., 2020).

The fugal figurations chart events that would not have happened without EJ's deep emersion in place and ability to shoulder the demands of engagement with partners for whom RSE matters. The urgency is what Temidayo Eseonu and James Duggan (this volume) refer to as a "non-trivial rationale" for co-production. EJ's long-term engagement as a government and third-sector consultant and advisor has enabled the development of an embodied and embedded knowledge of working practices across different sectors, organisations, the Senedd and policy and practice contexts in Wales. This has made it possible to mesh with other time scales and rhythms to achieve a "processual reciprocity" (Massumi, 2017, p. 31). Working in this way requires a high level of anticipation and the ability to respond in an instant (e.g. the tweet that sparked the proposal to develop the AGENDA resource) and in ways that take a long view of what might be possible (e.g. the professional learning programme offering an alternative praxis of coproducing a "living RSE curriculum"). This dexterity is also possible because we both have permanent positions in higher education institutions. Having a stable income provides security as well as challenges to our para-academic activist practices.

Like the improvisation in the Renaissance fugue, dartaphacts can take root and fly in ways unknown. Art-as-way can "runaway" and spin off in unforeseen directions. Indeed, none of the fugal figurations in this paper could have been predicted in advance. While fugues, in their repetition, build harmony in the gathering of multiple voices, we have also encountered disharmony as dartaphacts amplify and extend their reach. Dartaphacts have contributed to toxic media attention; attracted social media trolls; incited visible and invisible protest groups and led to personally targeted attacks. This is when the unwanted more-than of life's contingency enters co-production as uninvited forces. While participants feel the intensity or attack, posthuman dartaphacts continue to affect even when "queer response-ability" feels humanly unbearable. Slow co-production demands time, vigilance, fortitude and staying in place with an attitude of openness and a desire not to run from "the trouble" (Haraway, 2016) but to continue making with the trouble (Renold, in preparation). Well after this paper is 
published, dartaphacts will continue to sound the cries of what matters for children and young people in RSE creating new fugues. We are attuned to some, and others continue on their way below the radar of conscious awareness, affecting, worlding and living Otherwise. As Manning (2016, p. 25) suggests, "the unfolding affects us, moves us, directs us, but it does not belong to us”. Posthuman co-produced dartaphacts are more-than-human forces for change.

\section{Notes}

1. "PhEmaterialism" (Feminist Posthuman and New Materialisms in Education) was developed by EJ as a Twitter hashtag in 2015 for the network conference, Feminist Posthuman New Materialism: Research Methodologies in Education: "Capturing Affect". It has since become a network which "brings together a globally dispersed collective of students, researchers and artists experimenting with how posthuman and new materialism theories to form, in-form and reassemble educational research" (see www.phematerialism.org, and Renold and Ringrose, 2019).

2. https://senedd.wales/how-we-work/history-of-devolution/

3. https://gov.wales/consultation-lgbtq-action-plan-html

4. https://www.futuregenerations.wales/about-us/future-generations-act/

5. https://gov.wales/violence-against-women-domestic-abuse

6. https://gov.wales/childrens-rights-in-wales

7. The title of the project was "Making, Mapping and Mobilising in Merthyr (4 Ms): Using Creative Methods for Engaging Change with Young People. For details of this multi-phase ESRC/AHRC funded project and the Productive Margins programme, see https://productivemargins.blogs. bristol.ac.uk/projects (Reference: ES/K002716/1). The full research team for the 4 Ms project included: Eva Elliot, Eve Exley, Gabrielle Ivinson, Emma Renold and Gareth Thomas. NB. The first author changed their first name from Emma to EJ in 2020.

8. Co-authored by EJ Renold and Gabrielle Ivinson, this section of the AGENDA resource distils our arts-based praxis and focuses on becoming curious, imaginative, artful, multi-sensory, ethical and inclusive.

9. The AGENDA resource has reached over 7,000 young people and 3,500 educational practitioners between 2017 and 2020. See https://esrc.ukri.org/news-events-and-publications/impact-casestudies/transforming-relationships-and-sexuality-education/

10. Gabrielle Ivinson was an invited speaker during Meeting 4 "Exploring Creative and cross-curricular approaches for holistic and inclusive RSE".

11. This online professional learning conference for primary, secondary and special schools was organised by EJ Renold, Ester McGeeney, Leanne Coll and Kate Marston. Over 350 teachers and educators joined the conference. For the full programme conference, go to https://agendaonline.co. $\mathrm{uk} /$ making-agenda-matter/

\section{References}

Alldred, P. and Fox, N.J. (2019), "Assembling citizenship: sexualities education, micropolitics and the becoming-citizen”, Sociology, Vol. 53 No. 4, pp. 689-706.

Allen, L. (2018), Sexuality Education and New Materialism: Queer Things, Springer, New York.

Allen, L. (2020), "Sexuality education and feminist new materialisms", in Oxford Research Encyclopedia of Education, Oxford University Press.

Allen, L. and Rasmussen, M.L. (Eds) (2017), The Palgrave Handbook of Sexuality Education, Palgrave Macmillan, London, Buckingham.

Banks, A., Hart, A., Pahl, K. and Ward, P. (2019), Co-Producing Research: A Community Development Approach, Policy Press, Bristol. 
Barad, K. (2007), Meeting the Universe Halfway: Quantum Physics and the Entanglement of Matter and Meaning, Duke University Press, Durham.

Barad, K., Dolphijn, R. and Van der Tuin, I. (2012), "Matter feels, converses, suffers, desires, yearns and remembers", Interview with Karen Barad. In New Materialism: Interviews \& Cartographies. Ann Arbor, MI: Open Humanities Press, pp. 48-70.

Bell, D.M. and Pahl, K. (2018), "Co-production: towards a utopian approach. International”, Journal of Social Research Methodology, Vol. 21 No. 1, pp. 105-117.

Blaikie, F. (Ed.) (2021), Visual and Cultural Identity Constructs of Global Youth and Young Adults: Situated, Embodied and Performed Ways of Being, Engaging and Belonging, Routledge, London, New York.

Bozalek, V. and Zembylas, M. (2017), "Towards a response-able pedagogy across higher education institutions in post-apartheid South Africa: an ethico-political analysis", Education as Change, Vol. 21 No. 2, pp. $62-65$.

Coleman, R., Page, T. and Palmer, H. (2019), "Introduction. Feminist new materialist practice: the mattering of methods. MAI", Feminism and Visual Culture, Vol. 4, pp. 1-10.

Coll, L., Ollis, D. and O’Keeffe, B. (2019), "Rebel becomings", in Kjaran, J.I. and Saunstson, H. (Eds), Schools as Queer Transformative Spaces: Global Narratives on Sexualities and Gender, Routledge, London, pp. 54-69.

Dernikos, B., Lesko, N., McCall, S.D. and Niccolini, A. (Eds) (2020), Mapping the Affective Turn in Education: Theory, Research, and Pedagogy, Routledge, London, New York.

Donaldson, G. (2015), Successful Futures: Independent Review of Curriculum and Assessment Arrangements in Wales, Welsh Government, Wales.

Facer, K. and Pahl, K. (Eds) (2017), Valuing Interdisciplinary Collaborative Research: Beyond Impact, Policy Press, Bristol.

Ferfolja, T. and Ullman, J. (2017), "Gender and sexuality in education and health: voices advocating for equity and social justice", Sex Education, Vol. 17 No. 3, pp. 235-241.

Garland-Levett, S. (2020), "Knowing-in-being: traversing the mind/body dualism to dissolve sexuality education's 'knowledge/practice gap”, Gender and Education, Vol. 32 No. 6, pp. 697-714.

Gilbert, J. (2021), "Getting dirty and coming clean: sex education and the problem of expertise", Curriculum Inquiry, Vol. 51 No. 4, pp. 455-472.

Government Welsh (2020), Cross-cutting Themes for Designing Your Curriculum, Welsh Government, Wales, Hwb, [Online], available at: https://hwb.gov.wales/curriculum-for-wales/designing-yourcurriculum/cross-cutting-themes-for-designing-your-curriculum (accessed 9 January 2021).

Guatarri, F. (1995/2006), Chaosmosis: An Ethico-aesthetic Paradigm, Power Publications, Sydney.

Haraway, D. (1991), "Simians, cyborgs, and women", in The Reinvention of Nature, Free Association Books, London.

Haraway, D. (2016), "Staying with the trouble", in Making Kin in the Chthulucene, Duke University Press, Durham, London.

Hickey-Moody, A., Horn, C., Willcox, M. and Florence, E. (2021), Arts-Based Methods for Research with Children, Springer Nature, New York.

Huuki, T., Kyrölä, K. and Pihkala, S. (2021), "What else can a crush become: working with artsmethods to address sexual harassment in pre-teen romantic relationship cultures", Gender and Education, pp. 1-16, doi: 10.1080/09540253.2021.1989384.

Ivinson, G. and Renold, E. (2013), "Subjectivity, affect and place: thinking with Deleuze and Guattari's Body without Organs to explore a young girl's becomings in a post-industrial locale", Subjectivity, Vol. 6 No. 4, pp. 369-390.

Ivinson, G. and Renold, E. (2016), "Girls, camera,(intra) action: mapping posthuman possibilities in a diffractive analysis of camera-girl assemblages in research on gender, corporeality and place", in Posthuman Research Practices in Education, Palgrave Macmillan, London, pp. 168-185. 
King, T.L., Navarro, J. and Smith, A. (Eds) (2020), in , Otherwise Worlds: Against Settler Colonialism and Anti-blackness, Duke University Press, Durham, NC.

Kleinman, A. (2012), “Intra-Actions' (interview of Karen Barad by Adam Kleinman)”, Mousse, Vol. 34, pp. $76-81$.

Lea, T. (2020), Wild Policy: Indigeneity and the Unruly Logics of Intervention, Stanford University Press, Stanford, CA.

Libby, Georgia, Chloe, Courtney, Olivia, Rhiannon and Renold, E. (2018), "Making our feelings matters: using creative methods to re-assemble the rules on healthy relationships education in Wales", in Lombard, Nancy (Ed.), The Routledge Handbook of Gender and Violence, Taylor \& Francis, London, New York, pp. 303-319.

Lury, C. (2020), Problem Spaces: How and Why Methodology Matters, Polity Press, Cambridge.

Lury, C. and Wakeford, N. (Eds) (2012), Inventive Methods: The Happening of the Social, Routledge, London, New York.

Mamo, L., Fields, J., Gilbert, J. and Pereira, D. (2021), "Orienting toward possibility: girls and bisexuality at school”, Health Promotion Practice. doi: 10.1177/15248399211045019.

Manning, E. (2016), The Minor Gesture, Duke University Press, Durham, London.

Manning, E. (2020), For a Pragmatics of the Useless, Duke University Press, Durham, London.

Marston, K. (2020), Exploring Young People's Digital Sexual Cultures through Creative, Visual and Arts-Based Methods, Doctoral dissertation, Cardiff University, Cardiff.

Martino, W., Omercajic, K. and Cumming-Potvin, W. (2021), "YouTube as a site of desubjugation for trans and nonbinary youth: pedagogical potentialities and the limits of whiteness", Pedagogy, Culture and Society, Vol. 29 No. 5, pp. 753-772.

Massumi, B. (2013), Semblance and Event: Activist Philosophy and the Occurrent Arts, MIT Press, Cambridge, MA.

Massumi, B. (2015), Politics of Affect, Polity Press, Cambridge.

Massumi, B. (2017), The Principle of Unrest : Activist Philosophy in the Expanded Field, Open Humanities Press, London.

Mayes, E. (2019), "The mis/uses of 'voice' in (post) qualitative research with children and young people: histories, politics and ethics", International Journal of Qualitative Studies in Education, Vol. 32 No. 10, pp. 1191-1209.

Meissner, H. (2014), in Benavente, B., Ramos, A.M.G. and Nardini (coord.), K. (Eds), New Feminist Materialism: Engendering an Ethic-Onto-Epistemological Methodology, Artnodes, Open University of Catalonia, Catalonia, Vol. 14, pp. 35-41.

Mohandas, S. (2021), "Beyond male recruitment: decolonising gender diversification efforts in the early years by attending to pastpresent material-discursive-affective entanglements", Gender and Education, pp. 17-32, doi: 10.1080/09540253.2021.1884202.

Murris, K. (2020), Navigating the Post Qualitative, New Materialist and Critical Posthumanist Terrain across Disciplines: An Introductory Guide, Routledge, London.

Ollis, D., Coll, L., Harrison, L. and Johnson, B. (2022), Pedagogies of Possibility for Negotiating Sexuality Education with Young People, Emerald Publishing Ltd, Bingley, UK.

Osgood, J. and Robinson, K.H. (Eds) (2019), Feminists Researching Gendered Childhoods: Generative Entanglements, Bloomsbury Publishing, London.

Pahl, K.H. (2019), "Recognizing young people's civic engagement practices: rethinking literacy ontologies through co-production", Studies in Social Justice, Vol. 13 No. 1, pp. 20-39.

Pasley, A. (2020), "The effects of agential realism on sex research, intersexuality and education”, Sex Education. doi: 10.1080/14681811.2020.1858276.

Quinlivan, K. (2018), Exploring Contemporary Issues in Sexuality Education with Young People, Palgrave Macmillan, London. 
Renold, EJ (In preparation), "Making with the trouble: creative, curious and co-produced relationships and sexuality education", Gender and Education.

Renold, E. (2017), "Sex and relationship education should be about rights and equity not just biology", The Conversation, December 13, available at: https://theconversation.com/sex-and-relationshipeducation-should-be-about-rights-and-equity-not-just-biology-88806.

Renold, E. (2018), "Feel what I feel': making da(r)ta with teen girls for creative activisms on how sexual violence matters", Journal of Gender Studies, Vol. 27 No. 1, pp. 37-55.

Renold, E. (2019), "Becoming AGENDA: the making and mattering of a youth activist resource on gender and sexual violence", Reconceptualizing Educational Research Methodology, Vols 10, No. 2/3, pp. 208-241.

Renold, E. and Ivinson, G. (2019), "Anticipating the more-than: working with prehension in artful interventions with young people in a post-industrial community", Futures, Vol. 112, pp. 1-12.

Renold, E. and McGeeney, E. (2017a), The Future of the Sex and Relationships Education Curriculum in Wales, Welsh Government, Wales, available at: https://gov.wales/sites/default/files/ publications/2018-03/the-future-of-the-sex-and-relationships-education-curriculum-in-wales.pdf.

Renold, E. and McGeeney, E. (2017b), Informing the Future of the Sex and Relationships Education Curriculum in Wales, Cardiff University, Cardiff, available at: https://orca.cardiff.ac.uk/107648/.

Renold, E. and Ringrose, J. (2017), "Pin-balling and boners: the posthuman phallus and intra-activist sexuality assemblages in secondary school", in The Palgrave Handbook of Sexuality Education, Palgrave Macmillan, London, pp. 631-653.

Renold, E. and Ringrose, J. (2019), “JARing: making phematerialist research practices matter", MAI: Feminism and Visual Culture No. Spring Issue, available at: https://maifeminism.com/category/ focus-issue-intro/.

Renold, EJ., Ashton, M.R. and McGeeney, E. (2021), "What if?: becoming response-able with the making and mattering of a new relationships and sexuality education curriculum", Professional Development in Education, Vol. 47 Nos 2-3, pp. 538-555.

Renold, EJ., Edwards, V. and Huuki, T. (2019), "Becoming eventful: making the 'more-than' of a youth activist conference matter", Research in Drama Education: The Journal of Applied Theatre and Performance, Vol. 21 No. 3, pp. 441-464, doi: 10.1080/13569783.2020.1767562.

Renold, E., Holland, S., Ross, N.J. and Hillman, A. (2008), "Becoming participant' problematizing informed consent' in participatory research with young people in care", Qualitative Social Work, Vol. 7 No. 4, pp. 427-447.

Renold, E., Ivinson, G., Thomas, G. and Elliott, E. (2020a), "The Making, Mapping and Mobilising in Merthyr project: young people, research and arts activisms in a postindustrial place", Imagining Regulation Differently: Co-creating Regulation for Engagement, Bristol University Press, Bristol, pp. 127-143.

Renold, EJ., McGeeney, E. and Ashton, M.R. (2020b), CRUSH: Transforming Relationships and Sexuality Education, Cardiff University, Cardiff, available at: www.agendaonline.co.uk/crush/.

Ringrose, J., Warfield, K. and Zarabadi, S. (2020a), Feminist Posthumanisms, New Materialisms and Education, Routledge, London.

Ringrose, J., Whitehead, S. and Regehr, K. (2020b), "Play Doh Vulvas and felt tip dick pics: disrupting phallocentric matter (s) in sex education”, Reconceptualizing Educational Research Methodology, Vol. 10 Nos 2-3, pp. 259-291.

Snaza, N. and Mishra Tarc, A. (2019), “'To wake up our minds”: the re-enchantment of praxis in Sylvia Wynter", Curriculum Inquiry, Vol. 49 No. 1, pp. 1-6.

St. Pierre, E.A. (2017), "Post qualitative inquiry: the next generation", in Denzin, N. and Giardina, M. (Eds), Qualitative Inquiry in Neoliberal Times, Routledge, London/New York, pp. 45-55.

Stengers, I. (2019), "Putting problematization to the test of our present", Theory, Culture and Society, Vol. 38 No. 2, pp. $71-92$. 
Stewart, K. (2014), "Tactile compositions”, in Harvey, P., Conlin Casella, E., Evans, G., Knox, H., McLean, C., Silva, E.B., Thoburn, N. and Woodward, K. (Eds), Objects and Materials: A Routledge Companion, Routledge, London, pp. 119-127.

Strom, K., Ringrose, J., Osgood, J. and Renold, E. (2019), "PhEmaterialism Editorial”, Reconceptualizing Educational Research Methodology, Vol. 10 Nos 2-3, pp. 1-39.

Talburt, S. (Ed.) (2018), in , Youth Sexualities: Public Feelings and Contemporary Cultural Politics 2 Volumes], ABC-CLIO, Santa Barbara, CA.

Taylor, C., Quinn, J. and Franklin-Phipps, A. (2020), "Rethinking research 'use': reframing impact, engagement and activism with feminist new materialist, posthumanist and postqualitative research", in Murris, K. (Ed.), Navigating the Post Qualitative, New Materialist and Critical Posthumanist Terrain across Disciplines, Routledge, London.

Timperley, V. (2021), Making Gender Trouble: A Creative and Participatory Research Project with Neurodiverse Teen Gamers, Doctoral Dissertation, Cardiff University, Cardiff.

Todd, Z. (2016), "An indigenous feminist's take on the ontological turn: 'Ontology' is just another word for colonialism”, Journal of Historical Sociology, Vol. 29 No. 1, pp. 4-22.

Truman, S. (2019), "Feminist new materialisms", in Sage Research Methods Foundations, Sage Publications, London, pp. 1-13, doi: 10.4135/9781526421036.

Tuck, E. and McKenzie, M. (2014), Place in Research: Theory, Methodology, and Methods, Routledge, New York.

Welsh Government (2010), Sex and Relationships Education Guidance for Schools, Welsh Government, Wales.

Welsh Government (2015), Well-Being and Future Generations (Wales) Act 2015, Welsh Government, Wales.

Welsh Government (2015a), Violence against Women and Girls, Domestic Abuse and Sexual Violence (Wales) Act 2015, Welsh Government, Wales.

Welsh Government (2015b), A Whole Education Approach to Violence against Women, Domestic Abuse and Sexual Violence in Wales, Welsh Government, Wales, available at: https://www.cardiff.ac. uk/_data/assets/pdf_file/0007/522394/A-Whole-Education-Approach-to-Violence-AgainstWomen,-Domestic-Abuse-and-Sexual-Violence-in-Wales.pdf.

Welsh Government (2019), Written Statement: Launch of the Public Consultation on Updated Curriculum Guidance for Relationships and Sexuality Education, Welsh Government, Wales, available at: https://gov.wales/written-statement-launch-public-consultation-updatedcurriculum-guidance-relationships-and.

Welsh Government (2021), Draft Relationships and Sexuality Education Statutory Guide and Code, Welsh Government, Wales, available at: https://gov.wales/curriculum-wales-draft-rse-statutoryguidance-and-code.

Wolfe, M.J. (2021), Affect and the Making of the Schoolgirl: A New Materialist Perspective on Gender Inequity in Schools, Routledge, London, New York.

Zarabadi, S. (2021), Racialising Assemblages and Affective Events: A Feminist New Materialism and

Posthuman Study of Muslim Schoolgirls in London, Doctoral dissertation, University, College London.

\section{Corresponding author}

EJ Renold can be contacted at: renold@cf.ac.uk

For instructions on how to order reprints of this article, please visit our website:

www.emeraldgrouppublishing.com/licensing/reprints.htm

Or contact us for further details: permissions@emeraldinsight.com
Posthuman co-production 